\title{
Mass balance, ice velocity and ice temperature at the Inland Ice margin north-east of Jakobshavn, central West Greenland
}

\author{
Henrik Højmark Thomsen
}

Glaciological field investigations were made on the Inland Ice north-east of Jakobshavn. The work is part of the hydropower investigations at Pâkitsoq in a drainage basin proposed for a local hydropower project. Brief reports of the work have been given by Thomsen (1983, 1984, 1985, 1986).

\section{Mass balance measurements 1986/1987}

The glaciological programme was started in August 1982 when stakes were drilled into the ice for measuring the mass balance (fig. 1). The stakes were visited by helicopter on 13 May and 13 August. Six of the stakes are located near the ice margin ending in lake 187 (fig. 2 ) and are represented by stake 2 in fig. 1 . The stakes have been plotted on the most recent map of the area, based on aerial photographs from 1985 (see Thomsen, 1988).

The winter snow cover on the ice was very patchy and confined mainly to drifts in gullies and crevasses up to an elevation of about $500 \mathrm{~m}$ a.s.l., but snow cover was continuous at higher elevations. The transient balance for the winter period was measured in snow pits and by depth soundings at the stakes. As there were no signs of heavy melting during the winter, the observed distribution of snow cover is probably due to wind drifting. At elevations of about $500 \mathrm{~m}$ a.s.1. the 1987 summer ablation is high compared to earlier years.

At lower elevations the stakes were melted out confirming strong melting during the summer. The transient and annual balances are shown in Table 1 . In the case of stakes which melted out, a minimum balance figure can be given based on the length of the stake still in the ice at the time of the spring stake readings. These figures are given in brackets in Table 1.

\section{Ice temperature measurements}

To measure englacial temperatures two sets of thermistor strings were drilled down to depths of $202 \mathrm{~m}$ and $300 \mathrm{~m}$ in the ablation area (fig. 2). The holes were drilled with a newly constructed hot water drill (see Olesen \& Clausen, 1988). The drilling operation was carried out from a base camp established on the ice. The $202 \mathrm{~m}$ hole is situated $4.4 \mathrm{~km}$ upstream from the ice margin with an ice-surface elevation of $490 \mathrm{~m}$ a.s.l. The

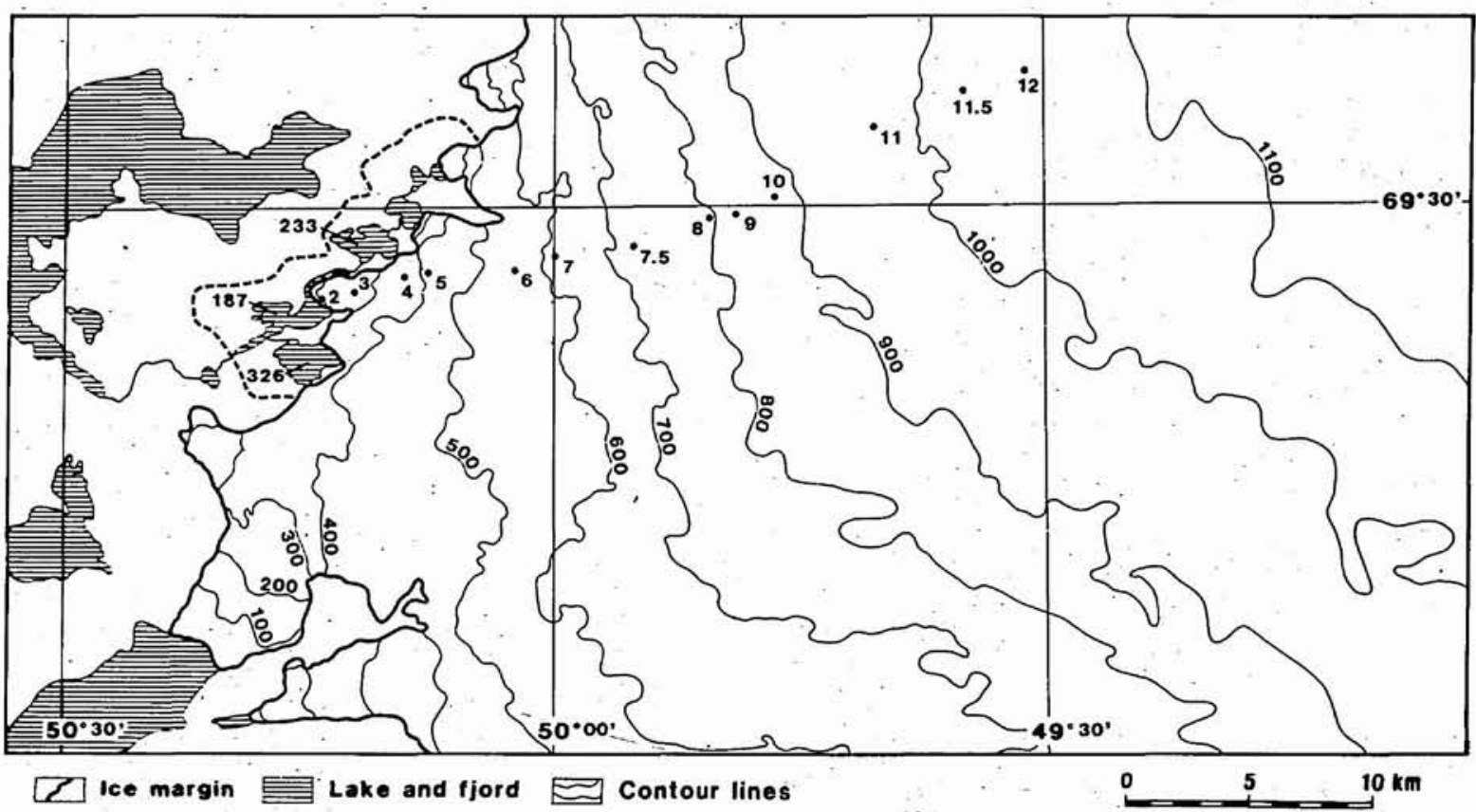

Fig. 1. Drainage basin at Pâkitsoq. Stakes drilled into the ice are shown. Contours in metres. 
Table 1. Transient and annual balances for the Inland Ice at Pâkitsoq millimetres of water

\begin{tabular}{rrrrr}
\hline Stake & $\begin{array}{r}\text { Elevation } \\
\text { m a.s.1. }\end{array}$ & $\begin{array}{r}\text { 25th Aug 86 } \\
\text { 13th May 87 }\end{array}$ & $\begin{array}{c}\text { 13th May } 87 \\
\text { 13th Aug 87 }\end{array}$ & $\begin{array}{r}\text { 25th Aug } 86 \\
\text { 13th Aug } 87\end{array}$ \\
\hline & & & & \\
2.0 & 210 & -580 & $>(-2900)$ & $>(-3500)$ \\
2.1 & 205 & -850 & $>(-2900)$ & $>(-3800)$ \\
2.2 & 205 & -800 & $>(-2900)$ & $>(-3700)$ \\
2.3 & 200 & -740 & $>(-2800)$ & $>(-3600)$ \\
2.4 & 200 & -810 & $>(-2800)$ & $>(-3600)$ \\
2.5 & 200 & -560 & $>(-2900)$ & $>(-3500)$ \\
3.0 & 235 & -630 & $>(-2900)$ & $>(-3500)$ \\
4.0 & 380 & -570 & $>(-2700)$ & $>(-3300)$ \\
5.0 & 415 & -560 & $>(-3200)$ & $>(-3800)$ \\
6.0 & 560 & -100 & -2080 & -2180 \\
7.0 & 615 & -180 & -1980 & -2160 \\
7.5 & 720 & -70 & -2000 & -2080 \\
8.0 & 780 & 140 & -2370 & -2230 \\
9.0 & 850 & 60 & -2270 & -2210 \\
10.0 & 890 & 130 & -1560 & -1430 \\
11.0 & 965 & 140 & -1750 & -1620 \\
11.5 & 1020 & 140 & -1580 & -1430 \\
12.0 & 1070 & 340 & $-480 *$ & $-130 *$ \\
\hline
\end{tabular}

* estimated.

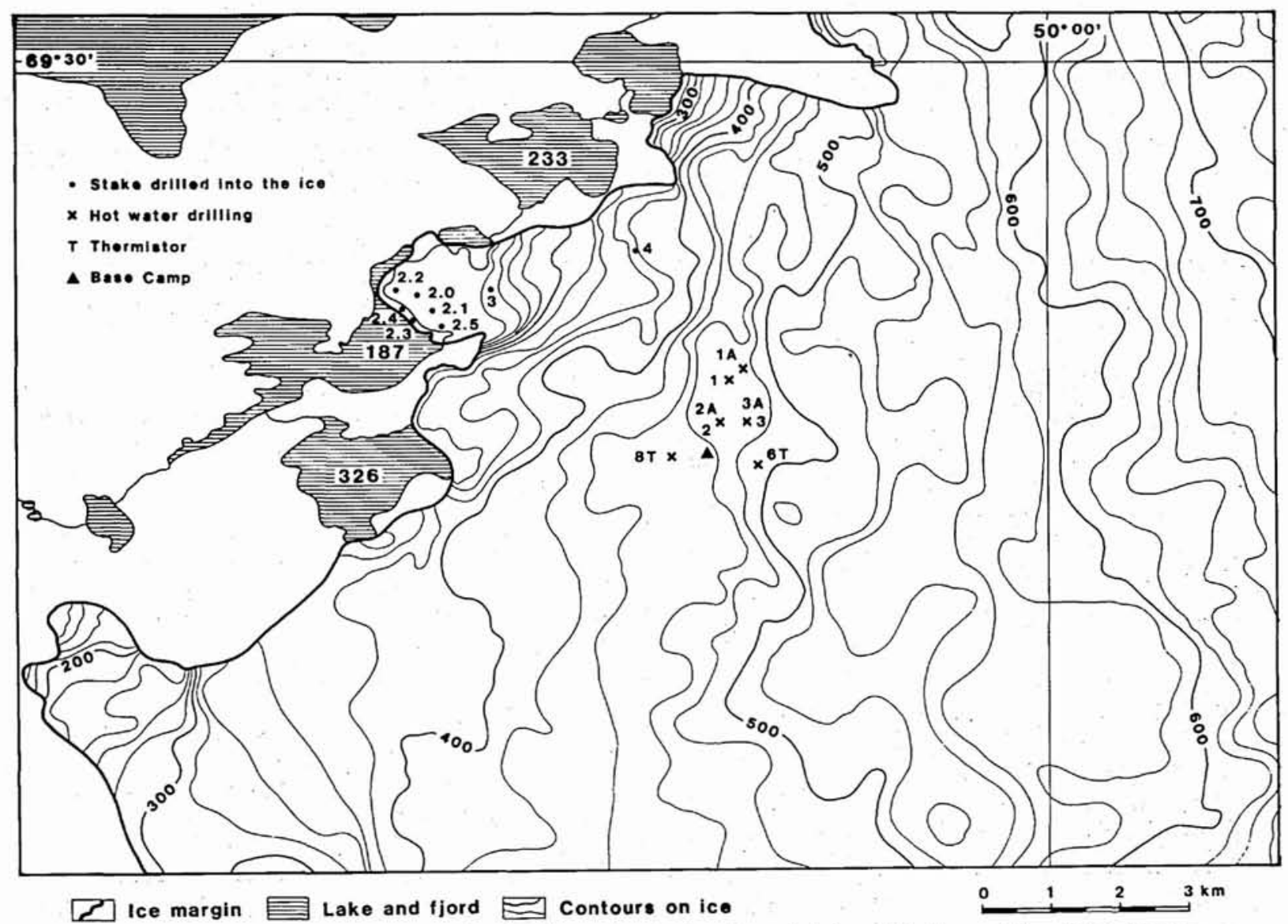

Fig. 2. Sector of drainage basin near ice margin at Pâkitsoq showing locations of stakes, drill sites and thermistor strings. 
ice thickness at this location is $300 \mathrm{~m}$ according to radio echo soundings (Thorning \& Hansen, 1987). The $300 \mathrm{~m}$ hole which extends to the bottom of the ice in accordance with radar measurements is situated $3.2 \mathrm{~km}$ upstream from the ice margin with an ice surface elevation of $455 \mathrm{~m}$ a.s.l.

Thermistors were mounted at every $25 \mathrm{~m}$ on the strings except for the lower end where the distance between the three lowest thermistors were 10 and $15 \mathrm{~m}$, respectively. The accuracy of the temperature measurements in the ice is $\pm 0.2^{\circ} \mathrm{C}$. Temperature readings were made several times during the two weeks duration of the drilling operation and were read five weeks later by a visiting field team from Greenland Technical Organisation (GTO). Temperature readings of thermistors drilled into the ice with a hot water drill on White Glacier, Axel Heiberg Island, showed temperatures to be sufficiently close to the equilibrium state to allow measurements after 2 to 3 weeks (Blatter, 1985). The latest readings at Pâkitsoq are assumed to be close to the equilibrium state, but exact verification is needed next year. The temperature readings reveal negative temperatures in the whole ice body and a small range through the profiles with a minimum temperature of $-2.1^{\circ} \mathrm{C}$ and a maximum temperature of $-0.6^{\circ} \mathrm{C}$. Temperature measured at the bottom of the ice is $-0.9^{\circ} \mathrm{C}$.

\section{Ice velocity measurements}

Ice velocity was measured on the glacier tongue ending in lake 187 . Ice velocity is measured by theodolite survey at stakes drilled into the ice from fixed points established on the ground. Ice velocities are given in Table 2 and stake locations are given in fig. 2. Ice movement is highest at stake 3 located at the foot of a small icefall. For the stakes near to the ice margin there is generally a higher velocity at the southern lateral part of the tongue compared to the central part. For all stakes there is a marked seasonal variation in ice movement, with mean summer velocities up to twice the mean winter velocity. Variations in sliding velocity could be an explanation (Paterson, 1981; Andreasen, 1985) which in turn implies that the basal ice is at the melting point and that surface meltwater can penetrate to the bed and build up high water pressure. It is not possible at present to determine if this movement pattern applies to the whole marginal area as no velocity measurements have been made further upstream. From depth soundings in lake 187 and ice thickness measurements with radar, it is reasonable to believe that the glacier tongue is floating. Water level recordings in lake 187 show that the mean water level is $2 \mathrm{~m}$ higher in summer $(G T O, 1983)$. The possibility that the move-
Table 2. Ice velocity on the margin of the Inland Ice at Pakitsoq

metres per day

\begin{tabular}{lccc}
\hline Stake & $\begin{array}{l}\text { 31st May 86 } \\
\text { 15th Sep 86 }\end{array}$ & $\begin{array}{c}\text { 15th Sep 86 } \\
\text { 15th May 87 }\end{array}$ & $\begin{array}{c}\text { 31st May 86 } \\
\text { 15th May 87 }\end{array}$ \\
\hline 2.0 & 0.10 & 0.05 & 0.06 \\
2.1 & 0.15 & 0.08 & 0.09 \\
2.2 & 0.09 & 0.04 & 0.06 \\
2.3 & 0.13 & 0.08 & 0.09 \\
2.4 & 0.10 & 0.06 & 0.07 \\
2.5 & 0.18 & 0.09 & 0.12 \\
3 & 0.30 & 0.19 & 0.23 \\
4 & 0.14 & - & - \\
\hline
\end{tabular}

- Stake not seen. See fig. 2 for stake locations.

ment pattern is connected with a floating ice tongue and thus is of local origin cannot be excluded.

Acknowledgements. Bo Madsen, (GTO) helped to survey the stakes, and Peer Jørgensen (GTO) helped with last thermistor readings.

\section{References}

Andreasen, J. O. 1985: Seasonal surface-velocity variations on a sub-polar glacier in West Greenland. J. Glaciol. 31, 319323.

Blatter, H. 1985: On the thermal regime of Arctic valley glaciers; a study of the White Glacier, Axel Heiberg Island, and the Laika Glacier, Coburg Island, N.W.T., Canada. Zürich: Eidgenössische Technische Hochschule, Geographisches Institut (Züricher Geographische Schriften 22).

GTO 1983: Vandkraftforundersøgelser Paakitsup Akuliarusersua Ilulissat/Jakobshavn 1983. København: Rapp. Grønlands Tek. Org., 43 pp.

Olesen, O. B. \& Clausen, A. 1988: Test drilling with a hot water jet at the Inland Ice margin, Pâkitsup, central West Greenland. Rapp. Grønlands geol. Unders. 140.

Paterson, W. S. B. 1981: The physics of glaciers, 2nd ed., 380 pp. Oxford: Pergamon Press.

Thomsen, H. H. 1983: A glaciological field and mapping programme in connection with hydropower, West Greenland. Rapp. Grønlands geol. Unders. 115, 102-107.

Thomsen, H. H. 1984: Glaciological reconnaissance, mass balance measurements and mapping programmes in connection with Greenland hydropower. Rapp. Grønlands geol. Unders. 120, 95-99.

Thomsen, H. H. 1985: Glaciological field work and remote sensing in connection with hydropower investigations, West Greenland. Rapp. Grønlands geol. Unders. 125, 95-99.

Thomsen, H. H. 1986: Is og Vandkraft. Glaciologi i vandkraftprojektet bynære bassiner, 1982-1986. Glaciology and hydropower. Glaciology for local hydropower projects, 19821986. Gronlands, geol. Unders. Gletscher-hydrol. Meddr 86/2, 73 pp. 
Thomsen, H. H. 1988: Mapping and modelling of glacier drainage in the Pâkitsoq basin, central West Greenland. Rapp. Grønlands geol. Unders. 140.
Thorning, L. \& Hansen, E. 1987: Electromagnetic reflection survey 1986 at the Inland Ice margin of the Pakitsoq basin, central West Greenland. Rapp. Grønlands geol. Unders. $135,87-98$.

\title{
Mapping and modelling of glacier drainage in the Pâkitsoq basin, central West Greenland
}

\author{
Henrik Højmark Thomsen
}

Mapping of surface hydrology and modelling of glacier hydraulics at the margin of the Inland Ice north-east of Jakobshavn have been used for investigating glacier drainage. The work is part of the hydropower investigations at Pâkitsoq in a drainage basin proposed for a local hydropower project. Excluding its Inland Ice sector the basin covers an area of $33.6 \mathrm{~km}^{2}$ and is situated at about 200-600 m a.s.l. (fig. 1; Thomsen, 1988, fig. 1). The main part of the runoff from the basin is meltwater from the ice sheet draining through three lakes, 326, 233 and 187. Lake 187 and 233 are proposed as two separate reservoirs, with tunnels leading to the fjord north-west of the basin.

\section{Glacier hydrological conditions}

Meltwater drainage on the ice itself is complicated. Over large areas meltwater drains through innumerable rivers whose drainage courses are influenced by the surface undulation and different structural features on the ice surface. In most cases the rivers escape down into moulins or crevasses, after which the meltwater drainage is controlled by englacial and subglacial drainage conditions. Delineation of drainage basins requires information about supraglacial and subglacial conditions.

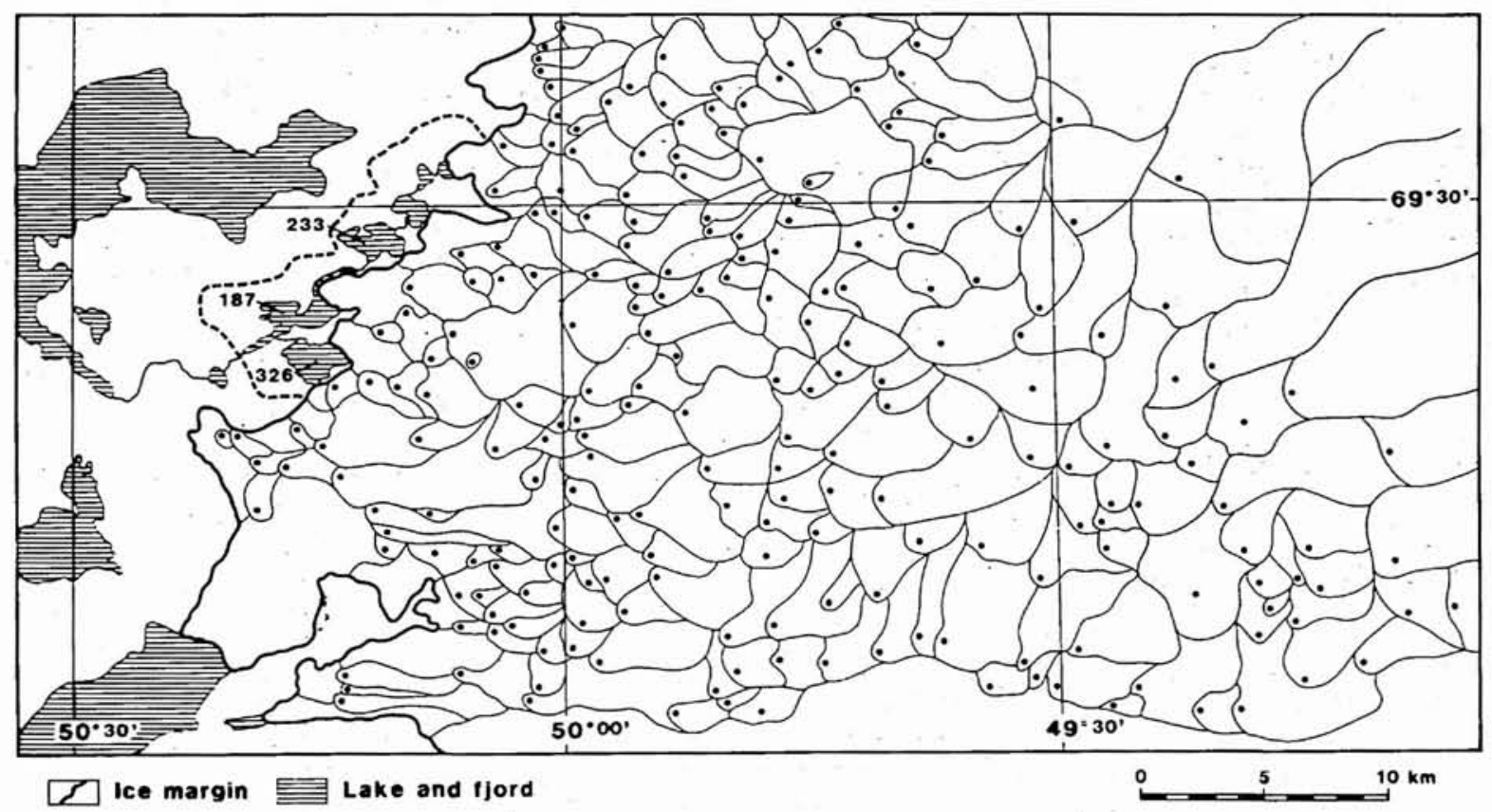

Fig. 1. Drainage cells on the Inland Ice at Pâkitsoq, each draining to a moulin or moulin complex. 